\title{
Social representation regarding the use of alcoholic beverages by adolescents
}

\author{
Representação social sobre o uso de bebidas \\ alcoólicas por adolescentes
}

\author{
Luciane Maya YAMAUCHI ${ }^{1}$ (D) 0000-0002-3510-821X \\ André Luiz Monezi ANDRADE² (D) 0000-0003-0111-8935 \\ Bruno de Oliveira PINHEIRO3 (D) 0000-0002-3671-3171 \\ Sônia Regina Fiorim ENUMO² ID 0000-0001-9038-6151 \\ Denise de MICHELI ${ }^{3}$ iD) 0000-0001-8546-4354
}

\begin{abstract}
This study evaluated the Social Representations regarding the use of alcoholic beverages by adolescents $\left(N=386 ; M_{\text {age }}=15.6\right.$; $S D=1.94)$ based on the Theory of Social Representations. The following instruments were used: sociodemographic questionnaire, Drug Use Screening Inventory and Word Evocation Questionnaire. The Social Representations was evaluated from prototypical and similarity reviews, based on the Social Representation Theory and on the Central Nucleus Theory, and the other data were analyzed based on descriptive and inferential tests. The results indicated that $45.0 \%$ of the adolescents had consumed alcoholic beverages during the month before data collection, $24.5 \%$ of them with a certain regularity (more than three times a month). With regard to Social Representations it was observed that the words "beer" and "party" were the most evoked $(p<0.05)$. Alcohol consumption by adolescents was considered an acceptable social behavior as it is associated with positive thinking and with socializing characteristics among peers $(p<0.01)$.
\end{abstract}

Keywords: Adolescents; Alcohol abuse; Ethyl alcohol; Social representations.

$\because V$

1 Aichi University, Faculty of Education, Departament of Humanities. Aichi, Japan.

2 Pontifícia Universidade Católica de Campinas, Centro de Ciências da Vida, Programa de Pós-Graduação em Psicologia. Av. John Boyd Dunlop, s/n., Prédio Administrativo CCV, Jardim Ipaussurama, 13034-685, Campinas, SP, Brasil. Correspondência para/Correspondence to: A.L.M. ANDRADE. E-mail: <andre.andrade@puc-campinas.edu.br>.

3 Universidade Federal de São Paulo, Departamento de Psicobiologia, Unidade de Dependência de Drogas. São Paulo, SP, Brasil.

$\boldsymbol{\nabla} \mathbf{v} \boldsymbol{\nabla}$

Como citar este artigo/How to cite this article

Yamauchi, L. M., Andrade, A. L. M., Pinheiro, B. O., Enumo, S. R. F., \& Micheli, D. (2019). Social representation regarding the use of alcoholic beverages by adolescents. Estudos de Psicologia (Campinas), 37, el80098. http://dx.doi.org/10.1590/1982-02 $75201936 \mathrm{e} 180098$ 


\section{Resumo}

Este trabalho analisou as representações sociais sobre o uso de bebidas alcoólicas por adolescentes ( $N=386$;

$M_{\text {idade }}=15,6$; $\left.D P=1,94\right)$, com base na Teoria das Representações Sociais. Foram utilizados os seguintes instrumentos: questionário sociodemográfico, Drug Use Screening Inventory e Questionário de Evocação de Palavras. A representação social foi avaliada a partir de análises prototípicas e de similitude, com base na Teoria da Representação Social e na Teoria do Núcleo Central, enquanto os demais dados foram analisados a partir de testes descritivos e inferenciais. Os dados indicaram que 45,0\% dos adolescentes haviam consumido bebidas alcoólicas no mês anterior à coleta de dados, sendo $24,5 \%$ deles com certa regularidade, correspondente a mais que três vezes no mês. Em relação às representações sociais, observou-se que as palavras "cerveja" e "festa" foram as mais evocadas $(p<0,05)$. O consumo de álcool foi considerado um comportamento social aceitável, estando associado com pensamentos positivos e com características socializadoras entre os pares $(p<0,01)$.

Palavras-chave: Adolescentes; Álcool etílico; Abuso de álcool; Representação social.

It is well established that adolescence is a period of greater vulnerability and exposure to different risk behaviors, among them the use of alcohol and other drugs (Gray \& Squeglia, 2018). When one observes the behaviors of use and abuse of substance in adolescents, it is perceived that many adolescents experience or consume alcohol frequently, and the first use in life has turned to be ever more precocious; on average, the age is ten years, even though this is a prohibited substance and harmful for this age group (Willhelm et al., 2015). Data from the II Household Survey on Substance Use carried out in 267 Brazilian municipalities evidenced that $54.3 \%$ of adolescents between 12 and 17 years of age had already used alcohol (Carlini \& Galduróz, 2005). Additionally, some authors indicated that those college students who reported binge drinking patterns showed more chances to develop problems related to alcohol use (Bedendo, Andrade, Opalaye, \& Noto, 2017). In this connection, the use of substances interferes significantly with this process, which may lead to cognitive impairment that is often irreversible (Cosker et al., 2018). Moreover, there is evidence that the earlier the substance use, the higher the probability of developing addiction (Bell, Rodd, Engleman, Toalston, \& McBride, 2014; Cruz, Martins, \& Diniz, 2017).

Adolescence is characterized by a higher incidence of impulsive behaviors and a lower capacity of inhibitory control when compared to adulthood, which increases the chances of adopting risk behaviors that may also be due to the context in which adolescents live (Coutinho, Santos, Folmer, \& Puntel, 2013). Environmental factors have a significant impact on both the onset and maintenance of drinking habits and on the use of other drugs; it is also well known that during adolescence, friends are viewed as a priority and represent an overhelming social and behavioral reference, influencing adolescents' behaviors (Scalese et al., 2017). The group behavior often becomes sovereign, and new beliefs and attitudes are built that increase the odds of adolescents engaging in risky behaviors.

Because of the influence of peers and of the environment, many adolescents may be involved in the consumption of alcohol and other drugs adopting other risky behaviors and, therefore, the study of the construction of ideas and beliefs process in adolescence is crucial. In this sense, the Social Representation Theory (SRT) would help to better understand the influence of social variables in substance abuse because the SRT offers the opportunity to broadly observe the reality where the phenomenon is constructed, diffused and shared day-by-day (Moscovici, 2003). According to Moscovici (2003), Social Representations (SR) are conventions accepted by the group, determining their behavior in social life, resulting in the way social actors represent an object and the meaning of this object in their lives.

An essential theory for the understanding of SR is the Central Nucleus Theory, proposed by Abric (1998) in which the representations of a given object are organized around the core and the peripheral systems. According to this author, the core system is characterized for being historically constituted, because

2 it is rigid and inaccessible to contextual changes, and for uniting the central representations which guide the 
individuals' actions. The peripheral system, on the other hand, is formed by circumstantial representations, based on the individual's context and experiences.

The formation of an SR implies action, simultaneous individual and collective action, in which individuals take ownership of a particular thought, and the representations associated to them consolidate themselves, regulating their interpretations of the world, of themselves and influencing their behavior; therefore, the SR serves as a reference for the individuals' conduct in their environment (Espidula \& Santos, 2004; Rosa \& Nascimento, 2015). The comprehension about the SR of alcohol use by adolescents (as a psychosocial object) shows extreme relevance and meaning. Besides, it allows a better understanding of the reality of this social group at the intrapersonal and interpersonal level, providing the development of new approaches to drug prevention programs that take into account the influence of these representational aspects (Aresi, Fattori, Pozzi, \& Moore, 2016).

In this connection, this study aimed at identifying the social representations of the use of alcoholic beverages by adolescents and it evaluates variables that would potentially influence the construction of these representations.

\section{Method}

\section{Participants}

The sample comprised 386 adolescents from the $7^{\text {th }}$ grade Elementary School to the $3^{\text {rd }}$ year High School, aged between 11 and 18, from two private schools and three public schools in São Paulo city, Brazil. They were selected based on convenience criteria, considering the geographic aspect and the population number.

\section{Instruments}

A questionnaire on sociodemographic data was used that includes the following items: age, socioeconomic level, gender, schooling, and specific questions to assess the participants' familiarity with alcoholic beverages and their degree of coexistence with people who regularly consume alcoholic beverages.

The Drug Use Screening Inventory (DUSI) was used to assess the alcohol use pattern; it is composed of 15 questions that address problems associated with use, such as compulsion to use or craving, symptoms of tolerance, withdrawal, or involvement in accidents. In this study, we applied only the frequency table of substance use and area 1, regarding the tracking of consumption. This instrument was validated in Brazil by De Micheli and Formigoni (2002) and showed a good reliability coefficient $(a=0.88)$.

The Word Evocation Questionnaire was used to assess social representations about the use of alcohol. This questionnaire was specially designed for word evocation and can be adapted according to the object to be studied (Sá, 1996). In the present study, this questionnaire exhibited the following instruction: "Write the first five words that come to your mind when talking about alcoholic beverages", and the "Alcoholic beverages" was considered the inducing term. The importance of each of the five words was evaluated by using a scale ranging from 1 (not important) to 3 (very important). At the end of the questionnaire, there was a section to analyze the familiarity and degree of coexistence of participants with individuals who consume alcoholic beverages. 


\section{Procedures}

The selection of schools criteria aimed at including in the sample adolescents of Elementary and High School; all of them were contacted by mail (Invitation Letter) which was delivered personally to the school director, explaining the purpose of the study. After one week, the contact with the schools was resumed, and a meeting was scheduled for a more detailed explanation of the objectives of the study.

At the time of application of the questionnaires, the investigator started the activities by introducing himself to the adolescents, explaining the objectives of the study, ensuring the confidentiality of the data and anonymity of the questionnaires. The application of the instruments took about 45 minutes and, when the students concluded this process, they were asked to place the questionnaire filled out in an urn on the teacher's desk. The Research Ethics Committee of Universidade Federal de São Paulo (Unifesp) approved this study (Number: 00182016; CAAE: 252529416.3.0000.5505).

\section{Data Analyses}

The Chi-Square Test $\left(\chi^{2}\right)$ was used for nominal and categorical data and the effect size was calculated by using Cramer's $\vee$ Test based on the following degrees of freedom ( $d f=3$ [small effect ( 0 to 0.06 ), medium effect $(0.07$ to 0.17$)$, large effect $(0.18$ to 1$)$ ]. This procedure was based on a previous study of our group (Cruz, Scatena, Andrade, \& Micheli, 2018; Silva, Andrade \& De Micheli, 2018).

For the analysis of the SR, Vergès' Prototypical Analysis (PA) was carried out. The PA consists of discriminating freely evoked words from an inducing term, considering the evocation frequency of the word (F) and the Mean Order of Evocation (MOE) or readiness about other words. In this process, the words evoked promptly and with high frequency will be placed in the Central Core. Three evocations were adopted as minimum frequencies, eliminating $10 \%$ of the total number of words evoked once. The degree of importance attributed by the participants to each evoked word was also calculated on a scale of 1 to 3 , and the value obtained composed the Mean Order of Importance (MOI). This procedure was based on previous studies (Wachelke \& Wolter, 2011).

The centrality of the words observed in the PA was confirmed by using the Similarity Analysis, which seeks to describe the connection between the elements found in the prototypical composition of the SR nucleus. This technique is based on the Graph Theory and serves for evaluating which elements present more significant influence and relationships strength. In the present study, we constructed a graph of the Maximum Tree type, with indications of the weights corresponding to the relevant elements. This procedure was based on Wachelke (2009).

The software used for the descriptive analyzes was the Statistica 15.0 (Statsoft Inc ${ }^{\circledR}$ ), and for the prototypical and similarity analyses, we used the software IRAMUTEQ (Interface de R pour les Analyses Multidimensionnelles de Textes et de Questionnaires) version 0.7 Alpha 2. The significance level in all analyzes was $5 \%$.

\section{Results}

As shown in Table 1, out of 386 adolescents, most of them were from public schools, and more than half were male, aged between 11 and 18 years and lived with their parents. Regarding the socioeconomic level, almost 50\% were classified as class B2 (family income up to R\$2.535,00 in Brazilian currency, in 2016). Regarding alcohol use during the last month, $45 \%$ of the adolescents reported to have ingested alcoholic beverages, and more than $20 \%$ had a frequency higher than three times a month. 


\begin{tabular}{|c|c|c|c|}
\hline \multirow{2}{*}{ Characteristics } & \multicolumn{2}{|c|}{ Participants } & \multirow{2}{*}{$95 \% \mathrm{Cl}$} \\
\hline & $n$ & $\%$ & \\
\hline \multicolumn{4}{|l|}{ School } \\
\hline Public & 304 & 79.0 & [0.74-0.82] \\
\hline Private & 82 & 21.0 & {$[0.17-0.25]$} \\
\hline \multicolumn{4}{|l|}{ Gender } \\
\hline Male & 209 & 54.0 & [0.48 -0.59] \\
\hline Female & 173 & 45.0 & [0.40 - 0.50$]$ \\
\hline Missing data & 4 & 1.0 & \\
\hline \multicolumn{4}{|l|}{ Age range (years) } \\
\hline $11-12$ & 42 & 11.0 & {$[0.08-0.14]$} \\
\hline $13-14$ & 127 & 33.0 & [0.28 -0.38] \\
\hline $15-16$ & 101 & 26.0 & [0.21 -0.30] \\
\hline $17-18$ & 116 & 30.0 & {$[0.28-0.38]$} \\
\hline \multicolumn{4}{|l|}{ Living with } \\
\hline Mother and father & 230 & 59.5 & [0.54 -0.64] \\
\hline Only with mother & 71 & 18.5 & [0.14 - 0.22$]$ \\
\hline Only with father & 16 & 4.0 & {$[0.02-0.06]$} \\
\hline Others & 69 & 18.0 & {$[0.14-0.22]$} \\
\hline \multicolumn{4}{|l|}{ Social Classes } \\
\hline A & 16 & 4.0 & {$[0.02-0.06]$} \\
\hline B1 & 86 & 22.5 & {$[0.18-0.27]$} \\
\hline B2 & 189 & 49.0 & {$[0.43-0.54]$} \\
\hline C & 95 & 24.5 & {$[0.20-0.29]$} \\
\hline \multicolumn{4}{|c|}{ Use of alcohol during the last month before the interview } \\
\hline Did not use & 212 & 55.0 & {$[0.49-0.60]$} \\
\hline 1 to 2 times & 79 & 20.5 & {$[0.16-0.25]$} \\
\hline Between 3 to 9 times & 57 & 15.0 & {$[0.11-0.19]$} \\
\hline Between 10 to 20 times & 21 & 5.5 & {$[0.03-0.08]$} \\
\hline More than 20 times & 15 & 4.0 & {$[0.02-0.06]$} \\
\hline
\end{tabular}

Note: Cl: Confidence Interval.

Table 2 shows the alcohol consumption by age group. As they grew older, there was a progressive increase in the frequency of adolescents who had consumed alcoholic beverages during the last month compared with those who had not used any. The transition period between some ages deserves to be highlighted, especially from 13 to 14 years, with an increase of $102 \%$ in the number of alcohol users.

Regarding the Prototypic Analysis (Table 3), those words allocated in the quadrant corresponding to the Central Nucleus and the Periphery indicated a greater force regarding the evoked content, as well as those that best express how the group behaves about the object being studied. Those data described in the lower left quadrant are the elements of the contrast zone, and those located in the lower right quadrant are the most peripheral elements or the second periphery. The term "alcoholic beverages" was used to describe 1,930 inductions with the mention of 586 different words. Synonymous words were grouped into the same class, which was labeled the most normal and representative response; unrepresentative were considered 
words with less than three mentions. After the grouping and selection process, 218 words were obtained.

Considering the triad of criteria - Frequency $(f)$, Mean Order of Evocations (MOE) and Mean Order of Importance (MOI) -, we observed that in the presence of the inducing term "alcoholic beverages", although the word "beer" was the most often mentioned, the word "parties" was the most readily evoked and with a high level of importance. The word "accident" yielded a reasonable level of evocation, but the low frequency and low level of importance, suggested minor significance in the quadrant of the central core.

In the first periphery, the word "adolescence" presented a high frequency and level of importance; then the word "friends" that was not mentioned with high frequency but was promptly evoked, with a high level of importance. In the lower left quadrant, the words "relax" and "forget" were the most readily evoked

Table 2

A number of adolescents who used alcoholic beverages $(n=174)$ and who did not use $(n=212)$ in the last month according to age range

\begin{tabular}{|c|c|c|c|c|c|c|c|c|c|}
\hline \multirow{2}{*}{ Age } & \multicolumn{2}{|c|}{ Used } & \multirow{2}{*}{$95 \% \mathrm{Cl}$} & \multicolumn{2}{|c|}{ Did not use } & \multirow{2}{*}{$95 \% \mathrm{Cl}$} & \multirow{2}{*}{ Test } & \multirow{2}{*}{$p$} & \multirow{2}{*}{ Effect size } \\
\hline & $n$ & $\%$ & & $n$ & $\%$ & & & & \\
\hline $11-12$ & 8 & 4.6 & [0.02 -0.08] & 36 & 16.9 & [0.12 -0.22] & $\chi^{2}=202.1$ & $* * *$ & 0.62 \\
\hline $13-14$ & 33 & 18.9 & {$[0.13-0.25]$} & 106 & 50.0 & {$[0.46-0.56]$} & & & \\
\hline $15-16$ & 66 & 37.8 & [0.30 - 0.45$]$ & 52 & 24.5 & [0.18 - 0.30$]$ & & & \\
\hline $17-18$ & 67 & 38.7 & [0.31 -0.46$]$ & 18 & 8.6 & [0.05 -0.13] & & & \\
\hline
\end{tabular}

Note: ${ }^{* * *} p<0.001$. The effect size was calculated by Cramer's V Test. Cl: Confidence Interval; $p$ : significance level.

Table 3

The prototypical analysis performed by using the inductor term "alcoholic beverage"

\begin{tabular}{|c|c|c|c|c|c|c|c|c|}
\hline & \multicolumn{4}{|c|}{ Central Core } & \multicolumn{4}{|c|}{ 1st Periphery } \\
\hline & Evocations & $f$ & MOE & $\mathrm{MOI}$ & Evocations & $f$ & MOE & $\mathrm{MOI}$ \\
\hline \multirow{8}{*}{ 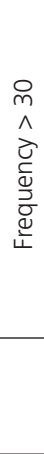 } & Beer & $128^{* *}$ & 2.3 & 2.6 & Adolescence & $96^{* *}$ & $3.8^{* *}$ & $2.9^{* *}$ \\
\hline & Parties & 124 & $2.0^{* *}$ & $2.9^{* *}$ & Fun & $88^{*}$ & $3.4^{*}$ & $2.8^{* *}$ \\
\hline & Accident & 42 & 2.4 & 1.4 & Hangover & 76 & $3.4^{*}$ & 2.6 \\
\hline & Drunkenness & 69 & 2.6 & 1.6 & Fights & 73 & 3.2 & 2.5 \\
\hline & Dependency & 81 & 2.6 & 1.8 & Friends & 48 & $3.7^{*}$ & $2.8^{* \star}$ \\
\hline & Death & 44 & 2.8 & 1.0 & Harmful & 35 & 3.1 & 1.9 \\
\hline & \multicolumn{4}{|c|}{ Contrasted Zone } & \multicolumn{4}{|c|}{$2^{\text {nd }}$ Periphery } \\
\hline & Evocations & $f$ & MOE & $\mathrm{MOI}$ & Evocations & $f$ & MOE & $\mathrm{MOI}$ \\
\hline \multirow{6}{*}{ 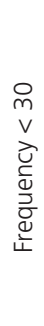 } & Uncontrolled & 29 & 2.7 & 2.3 & Moderation & 20 & 3.0 & 2.0 \\
\hline & Drug & 29 & 2.4 & 1.9 & Pranks & 22 & $3.6^{* *}$ & $2.4^{*}$ \\
\hline & Pub & 25 & 2.8 & 1.5 & Problems & 21 & 3.3 & $2.4^{*}$ \\
\hline & Bad & 19 & 2.7 & 1.9 & Sex & 21 & $3.4^{*}$ & $2.7^{* *}$ \\
\hline & Forget & 13 & $2.4^{*}$ & $2.4^{*}$ & Embarrassment & 14 & $3.5^{*}$ & $2.4^{*}$ \\
\hline & Relax & 12 & $2.0^{* *}$ & $2.8^{* *}$ & Music & 12 & $3.6^{*}$ & $2.4^{*}$ \\
\hline
\end{tabular}

Note: "Element with overhang in related criterion; ${ }^{* *}$ Element with overhang elevated in the relevant criterion. f: Frequency; MOE: Mean Order of Evocation; 
and had a high level of importance associated with the term "alcoholic beverages". The word "drug" was also mentioned promptly, but with a low level of importance. In the $2^{\text {nd }}$ periphery, the word "pranks" was readily evoked with a high level of importance. The words "weekend", "music", "sex" and "embarrassment" although mentioned in low frequency, were promptly evoked and with a high average of importance about the object being studied.

For the organization and articulation between the elements of a social representation obtained from the prototypical analysis, we used the Similarity Analysis (Figure 1) that showed the maximum tree similarity with the links corresponding to the words linked to the inducing term "alcoholic beverages". The strongest traits constitute relations (connection) of a serious nature and centrality; the basic lines represent the connection of medium intensity, and the dotted lines represent lower intensity in the relation. We considered the presence of two central organizing elements in the Social Representation on the use of alcoholic beverages among adolescents, namely: Parties and Adolescence - because both contain a higher frequency of articulations of words. Also, they represent the most prominent situations in the triad - frequency, MOE and MOI and, therefore, present centrality in the social representation in question.

In the maximum tree figure, a significant connection between some words and the organizing elements - "parties" and "adolescence" was detected. Celebration was strongly associated (high connection) with the presence of "friends", "fun" and "pranks". Additionally it was strongly related to "hangover", "fun" and "sex", and presented medium connection with "Problems", "Fights" and "Pranks".

When the association of adolescents with alcoholic beverages and living with alcohol users was associated (Table 4), it was detected that a higher number of them lived with their relatives $(62.5 \%)$ or friends (52.0\%) who consumed alcoholic beverages frequently.

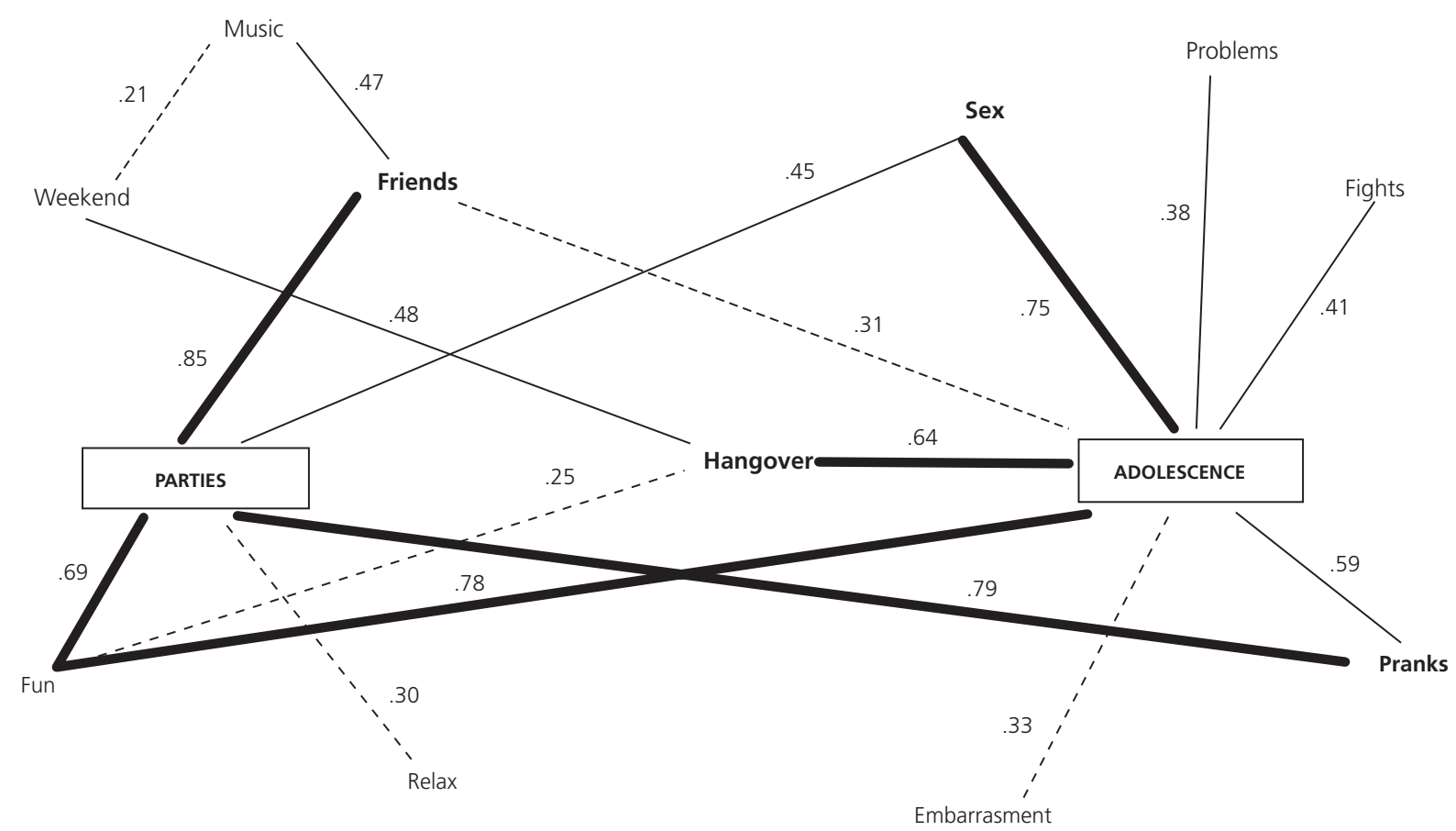

Figure 1. Maximum tree of similarity according to the adolescents' responses $(\mathrm{N}=386)$. The strongest traits constitute relations (connection) of a strong nature and centrality; the basic lines represent the connection of medium intensity, and the dotted lines represent lower intensity in the relationship.). Each edge represents the zero-order correlation between two variables, and thickness signifies magnitude. 
Mainly family and social influences reported among those adolescents who consume alcoholic beverages $(n=174)$

\begin{tabular}{|c|c|c|}
\hline \multirow{2}{*}{ Items } & \multicolumn{2}{|c|}{ Participants } \\
\hline & $n$ & $\%$ \\
\hline I do not have contacts with alcoholic beverages or with people who drink. & 40 & 23.0 \\
\hline I have little or no contact with alcoholic beverages and with people who drink. & 48 & 27.5 \\
\hline I live with family members who drink sometimes. & 108 & 62.5 \\
\hline I live with friends who drink sometimes. & 91 & 52.0 \\
\hline I live with family members and friends who drink frequently. & 45 & 26.0 \\
\hline If I want, I can quickly get alcoholic beverages. & 55 & 32.0 \\
\hline If my parents/family/guardians catch me drinking (or drunk), I will have problems. & 86 & 49.5 \\
\hline $\begin{array}{l}\text { If my parents/family/guardians catch me drinking (or drunk), there won't be a problem, after all they know that } \\
\text { it is a teenager thing. }\end{array}$ & 23 & 13.5 \\
\hline
\end{tabular}

\section{Discussion}

This study aimed at evaluating the social representations that adolescents have of the use of alcoholic beverages, and our main data indicated that a context of predominantly positive beliefs and attitudes are associated with alcohol consumption. In this connection, a high level of centrality was detected for the words "beer" and "parties" and the prototypical analyses indicated that the words "friends" and "fun" were highly connected to "parties", as observed in the maximum tree chart. It was also detected that $45 \%$ of the adolescents reported to have consumed alcoholic beverages during the last month before the interview and about $20 \%$ had drunk alcohol with a certain regularity (more than three times during the month).

The levels of consumption found in this study were higher than those observed in another Brazilian study, in which the prevalence of alcohol consumption by primary school students in the previous month was 26.1\% (Instituto Brasileiro de Geografia e Estatística, 2016). In another national survey carried out with a sample of school adolescents from 124 Brazilian municipalities, $68.0 \%$ mentioned having consumed alcohol about two times in the month preceding the interview (Coutinho et al., 2016). Other Brazilian studies with samples of school-aged adolescents also found similar prevalence (Malta et al., 2010; Raphaelli, Azevedo, \& Hallal, 2011).

It was observed that some adolescents from 11 to 12 years consumed alcohol, and this early age consumption was also detected by some authors (Paiva et al., 2015). According to some authors, the onset of alcohol consumption has become increasingly precocious (Bell et al., 2014), and indicates a significant aggravation, since it is well known that consumption at early ages is strongly associated with alcohol misuse (Andrade \& De Micheli, 2013). Additionally, we detected a progressive increase, as the adolescent grew older, in the frequency of consumption of alcoholic beverages, with some transient age groups, especially from 13 to 14 years of age, where there was an increase of $102.00 \%$ Similarly, Coutinho et al. (2016) conducted a study evaluating the prevalence of alcohol use in a school sample of $74.58 \%$ adolescents from 273 Brazilian municipalities and found a $127.00 \%$ increase in the frequency of alcohol users in the transition from the age group 12-14 years to $15-17$ years.

Our data indicated that about $20 \%$ of the adolescents reported living with friends and family who drink frequently and around $15 \%$ stated that they would not suffer any punishment if their parents saw them drinking or being drunk because this is a typical behavior of adolescence. In the same sense, some authors observed that those who believed that parents would not care if they got drunk at home were three 8 times more likely to increase their alcoholic beverages intake (Malta, Mascarenhas, Porto, Barreto, \& Neto, 
2014). On the other hand, studies indicate that family cohesion and supervision associated with the sense of belonging and connectivity to the family environment can act as protective factors, reducing the chances of adolescents' involvement in various risk behaviors (Silva, Rodrigues, De Micheli, \& Andrade, 2015).

Regarding the SR that adolescents have about the use of alcoholic beverages, the results indicated a context of predominantly positive beliefs and attitudes associated with the consumption of alcohol. Through the prototypical analysis, we identified the elements that were promptly evoked and with a high level of importance, thus highly significant for the understanding of the SR under study. High levels of centrality were detected for the words "beer" and "parties". If on the one hand, a large number of adolescents mentioned "beer" associated with the inducing term; on the other hand, "parties" was the most readily evoked word, which guarantees its centrality. Although beer advertising has a restriction period between 09:00 pm and 06:00 am, short advertisements can be broadcast at any time. In this connection, it can be inferred that the positive images associated with beer consumption, the production of beers with juvenile identity and the ease of obtaining them, since they do not fit into the "alcoholic beverages" hall, are responsible for the high prevalence of drinking among adolescents, as observed by some authors (Vendrame, Pinsky, Faria, \& Silva, 2009).

The prototypical analyses identified the words "friends" and "fun", highly connected to "parties", as observed in the maximum tree graph. The presence of friends as a factor associated with the motivation for alcohol consumption was detected by some authors (Bedendo, Opaleye, Andrade, \& Noto, 2013) and is due to the need for the adolescent to be identified with the group, as well as to the pressure that the group often exerts on the adolescent. In this respect, it is shown that the alcoholic beverage is perceived as a facilitator of this process. In the peripheral system, "adolescence" was identified as another organizing element of SR and it denotes the easiness and unconcern that many adolescents exhibit regarding the use of alcohol. Moreover, because alcohol is a lawful substance socially accepted further fosters this normative perception about consumption and positive belief about the substance, contributing to the increase in the pattern of consumption and the percentage of consumers.

The parties known as "open bar" are becoming increasingly popular in Brazil and are used by managers to attract more clients; many "open bars" operate on weekends, beginning in the late afternoon, favoring the presence of adolescents between 12 and 14 years of age. Studies have shown that open bar parties are associated with excessive alcohol consumption among adolescents and higher rates of violence in both the internal and external settings (Nguyen, Sendall, White, \& Young, 2018; Sanchez, 2017).

\section{Conclusion}

Taken together, our data indicated that the use of alcoholic beverages was considered as an acceptable behavior among adolescents and is associated with positive beliefs and socialization. In this connection, the use of alcohol among adolescents seems to be a controversial issue in itself, since society is incongruously positioned to approve publicity regulation and consumption of alcoholic beverages in favor of conscious and moderate use, but uses too much and/or tolerates or even allows consumption by younger people. Family behavior also exerts a strong influence on the use of alcohol by adolescents, through a permissive and tolerant attitude towards alcohol consumption. This study has limitations that have to be considered. First, this is a crossectional study and it is not possible to evaluate any causal relationship between the variables. The second limitation refers to the impossibility (and incompatibility) to compare the social representations of public and private school students, because the sample of public school students is much larger, and would then bias the results. 


\section{Contributors}

L.M. YAMAUCHI, D. MICHELI, and A. ANDRADE contributed to the conception and design, data analysis and interpretation, and discussion of the results. B.O. PINHEIRO and S.R.F ENUMO contributed to the data analysis and interpretation, and discussion of the results. All authors review and approval of the final version of the article.

\section{References}

Abric, J. C. (1998). A abordagem estrutural das representações sociais. In A. S. P. Moreira \& D. C. Oliveira (Orgs.), Estudos interdisciplinares de representação social (pp.27-38). Goiânia: AB.

Aresi, G., Fattori, F., Pozzi, M., \& Moore, S. C. (2016). I am going to make the most out of it! Italian university Credit Mobility Students' social representations of alcohol use during study abroad experiences. Journal of Health Psychology, 23(13), 1649-1658. http://dx.doi.org/10.1177\%2F1359105316666658

Andrade, A. L. M., \& De Micheli, D. (2013). Cognitive aspects of fetal alcohol syndrome in young adults: Two case studies. Interação em Psicologia, 17(2), 217-223. http://dx.doi.org/10.5380/psi.v17i2.27359

Bedendo, A., Opaleye, E. S., Andrade, A. L. M., \& Noto, A. R. (2013). Heavy episodic drinking and soccer practice among high school students in Brazil: The contextual aspects of this relationship. BMC Public Health, 13(1), 247-255. http:// dx.doi.org/10.1186/1471-2458-13-247

Bedendo, A., Andrade, A. L. M., Opaleye, E. S., \& Noto, A. R. (2017). Binge drinking: A pattern associated with a risk of problems of alcohol use among university students. Revista Latino-Americana de Enfermagem, 25, e2925. http:// dx.doi.org/10.1590/1518-8345.1891.2925

Bell, R. L., Rodd, Z. A., Engleman, E. A., Toalston, J. E., \& McBride, W. J. (2014). Scheduled access to alcohol drinking by alcohol-preferring $(P)$ and high-alcohol-drinking (HAD) rats: Modeling adolescent and adult binge-like drinking. Alcohol, 48(3), 225-234. http://dx.doi.org/10.1016/j.alcohol.2013.10.004

Carlini, E. A., \& Galduróz, J. C. F. (2005). II levantamento domiciliar sobre o uso de drogas psicotrópicas no Brasil: estudo envolvendo as 108 maiorescidades do país. São Paulo: Centro Brasileiro de Informações sobre Drogas Psicotrópicas - CEBRID/SENAD. Recuperado em agosto 26, 2018, de https://www.cebrid.com.br/wp-content/ uploads/2014/10/I-LevantamentoDomiciliar-sobre-o-Uso-de-Drogas-Psicotr\%C3\%B3picas-no-Brasil.pdf

Cosker, E., Schwitzer, T., Ramoz, N., Ligier, F., Lalanne, L., Gorwood, P., ... Laprévote, V. (2018). The effect of interactions between genetics and cannabis use on neurocognition: A review. Progress in Neuro-Psychopharmacology and Biological Psychiatry, 82(2), 95-106. http://dx.doi.org/10.1016/j.pnpbp.2017.11.024

Coutinho, R. X., Santos, W. M. Folmer, V., \& Puntel, R. L. (2013). Prevalência de comportamentos de risco em adolescentes. Cadernos de Saúde Coletiva, 21(4), 441-449. http://dx.doi.org/10.1590/S1414-462X2013000400013

Coutinho, E. S. F., França-Santos, D. Magliano, E. S., Bloch, K. V., Barufaldi, L. A., Cunha, C. F., ... Szklo, M. (2016). ERICA: Patterns of alcohol consumption in Brazilian adolescents. Revista de Saúde Pública, 50(1), 1-9. http://dx.doi. org/10.1590/s01518-8787.2016050006684

Cruz, E. L. D., Martins, P. D., \& Diniz, P. R. B. (2017). Factors related to the association of social anxiety disorder and alcohol use among adolescents: A systematic review. Jornal de Pediatria, 93(5), 442-451. http://dx.doi.org/10.1016/j. jped.2017.05.001

Cruz, F. A. D., Scatena, A., Andrade, A. L. M., \& Micheli, D. D. (2018). Evaluation of Internet addiction and the quality of life of Brazilian adolescents from public and private schools. Estudos de Psicologia (Campinas), 35(2), 193-204. http://dx.doi.org/10.1590/1982-02752018000200008

De Micheli, D., \& Formigoni, M. L. (2002). Psychometric properties of the Brazilian version of the drug use screening inventory. Alcoholism: Clinical and Experimental Research, 26(10), 1523-1528. http://dx.doi.org/10.1097/01. ALC.0000033124.61068.A7

Espidula, D. H. P., \& Santos, M. F. S. (2004). Representations on adolescence by the educators of juvenile transgressors. Psicologia em Estudo, 9(3), 357-367. http://dx.doi.org/10.1590/S1413-73722004000300004

Gray, K. M., \& Squeglia, L. M. (2018). Research review: What have we learned about adolescent substance use? Journal of Child Psychology and Psychiatry, 59(6), 618-627. http://dx.doi.org/10.1111/jcpp.12783

Instituto Brasileiro de Geografia e Estatistica. (2016). Pesquisa nacional de saúde do escolar: 2015. Rio de Janeiro: Autor. Recuperdo em agosto 26, 2018, de https://biblioteca.ibge.gov.br/visualizacao/livros/liv97870.pdf 
Malta, D. C., Sardinha, L. M. V., Mendes, I., Barreto, S. M., Giatti, L., Castro, I. R. R., ... Crespo, C. (2010). Prevalence of risk health behavior among adolescents: Results from the 2009 National Adolescent School-based Health Survey (PeNSE). Ciência \& Saúde Coletiva, 15(2), 3009-3019. http://dx.doi.org/10.1590/S1413-81232010000800002

Malta, D. C., Mascarenhas, M. D. M., Porto, D. L., Barreto, S. M., \& Neto, O. L. M. (2014). Exposição ao álcool entre escolares e fatoresassociados. Revista de Saúde Pública, 48(1), 52-62. http://dx.doi.org/10.1590/S0034-8910.2014048004563

Moscovici, S. (2003). Representações sociais: investigações em psicologia social. Petrópolis: Vozes.

Nguyen, T. T. H., Sendall, M. C., White, K. M., \& Young, R. M. (2018). Vietnamese medical students and binge drinking: A qualitative study of perceptions, attitudes, beliefs and experience. BMJ Open, 8(4), e020176. http://dx.doi. org/10.1136/bmjopen-2017-020176

Paiva, P. C. P., Paiva, H. N. Lamounier, J. A., Ferreira, E. F. César, C. A. S., \& Zarzar, P. M. (2015). Binge drinking among 12-year-old adolescent schoolchildren and its association with sex, socioeconomic factors and alcohol consumption by best friends and family members. Ciência \& Saúde Coletiva, 20(11), 3427-3435. http://dx.doi.org/10.1590/1413812320152011.18792014

Raphaelli, C. O., Azevedo, M. R., \& Hallal, P. C. (2011). Association between health risk behaviors in parents and adolescents in a rural area in southern Brazil. Cadernos de Saúde Pública, 27(12), 2429-2440. http://dx.doi.org/10.1590/S0102$311 \times 2011001200014$

Rosa, F. A. L., \& Nascimento, A. R. A. (2015). Social Representations of alcohol for male college students. Arquivos Brasileiros de Psicologia, 67(1), 3-19. Retrieved August 26, 2018, from http://pepsic.bvsalud.org/pdf/arbp/v67n1/02.pdf

Sá, C. P. (1996). Núcleo central das representações sociais. São Paulo: Vozes.

Sanchez, Z. M. (2017). Binge drinking among young Brazilians and the promotion of alcoholic beverages: A public health concern. Epidemiologia e Serviços de Saúde, 26(1), 195-198. http://dx.doi.org/10.5123/s1679-49742017000100020

Scalese, M., Denoth, F., Siciliano, V., Bastiani, L., Cotichini, R., Cutilli, A., \& Molinaro, S. (2017). Energy drink and alcohol mixed energy drink use among high school adolescents: Association with risk taking behavior, social characteristics. Addictive Behaviors, 72, 93-99. http://dx.doi.org/10.1016/j.addbeh.2017.03.016

Silva, M. A. A., Andrade, A. L. M., \& De Micheli, D. (2018). Evaluation of the Implementation of Brief Interventions to Substance Abuse in a Socieducative Context. Revista Psicologia em Pesquisa, 12(1), 1-10. http://dx.doi.org/10. 24879/2018001200100125

Silva, E. A. D., Rodrigues, T. P., De Micheli, D., \& Andrade, A. L. M. (2015). Strategies for treating families affected by substance abuse users. Psicologia em Pesquisa, 9(2), 198-204. http://dx.doi.org/10.5327/Z1982-1247201500020010

Vendrame, A., Pinsky, I., Faria, R., \& Silva, R. (2009). Brazilian teenagers and beer advertising: Relationship between exposure, positive response, and alcohol consumption. Cadernos de Saúde Pública, 25(2), 359-365. http://dx.doi. org/10.1590/S0102-311X2009000200014

Wachelke, J. (2009). Social Representations Centrality Index from Evocations (INCEV): An example of application on the study of the social representation on aging. Psicologia: Reflexão e Crítica, 22(1), 102-110. http://dx.doi.org/10.1590/ S0102-79722009000100014

Wachelke, J., \& Wolter, R. (2011). Criteria related to the realization and reporting of prototypical analysis for social representations. Psicologia: Teoria e Pesquisa, 27, 521-526. http://dx.doi.org/10.1590/S0102-37722011000400017

Willhelm, A. R., Cabral, J. C. C., Steiger, J. O., da Silva, J. F. F., Ugarte, L. M., \& de Almeida, R. M. M. (2015). Consumo de álcool na adolescência e relação com uso excessivo de bebidas alcóolicas dos pais: estudantes de quatro escolas de Porto Alegre. Psico, 46(2), 208-216. http://dx.doi.org/10.15448/1980- 8623.2015.2.18129

Received: August 27, 2018

Final version: May 2, 2019

Approved: May 16, 2019 